\title{
UPAYA MENINGKATKAN PEMAHAMAN SANTRI PADA PEMBELAJARAN FIQIH THAHARAH MELALUI MEDIA AUDIO VISUAL
}

\author{
Fathor Rozi \& Ummi Hanik Alawiyah \\ Universitas Nurul Jadid \\ fathorrozi330@gmail.com,hannywiyah@gmail.com
}

\begin{abstract}
TPQ Al-Istiqomah in the process of learning fiqh thaharah uses the lecture method. The use of the lecture method is deemed ineffective to use in the delivery of this thaharah material, because santri tend to be bored, sleepy and less focused, besides that there are some materials in thaharah that are needed by ssntri concentration in the process of understanding. Therefore it takes a method or learning media that is more attractive and appropriate to the age of the santri, the media is an audio-visual learning media, this media will awaken more of the santri senses in the learning process. The purpose of this research is to improve the learning of thaharah figh material for santri so that they can understand thaharah and can practice and practice it in everyday life. The conclusion of this study is that it is proven that the use of audio-visual learning media is proven to be more effective in increasing understanding of the learning material of figh thaharah compared to the previous learning method, namely lectures. This is evident from the results of the evaluation of the students' learning at the end of the lesson in the form of prayer reading, memorization and practice.
\end{abstract}

Keywords: Fiqh, Thaharah, Media, Audio, Visual

\begin{abstract}
Abstrak : TPQ Al-Istiqomah dalam proses pembelajaran fiqih thaharah menggunakan metode ceramah. Penggunaan metode ceramah dirasa kurang efektif untuk digunakan dalam penyampaian materi thaharah ini, karena santri cenderung bosan, mengantuk dan kurang fokus, selain itu terdapat beberapa materi dalam thaharah yang sangat dibutuhkan konsentrasi santri dalam proses pemahamannya. Oleh sebab itu dibutuhkan metode atau media pembelajaran yang lebih menarik dan sesuai dengan usia santri, media tersebut adalah media pembelajaran audio visual, media ini akan membangkitkan lebih banyak alat indra santri dalam proses belajar mengajar. Tujuan dari penelitian ini ialah untuk meningkatkan pembelajaran fiqih materi thaharah kepada santri agar mereka bisa memahami thaharah dan dapat mengamalkan dan mempraktekkannya dalam kehidupan sehari-hari. Kesimpulan dari penelitian ini terbukti bahwa penggunaan media pembelajaran audio visual terbukti lebih efektif dalam meningkatkan pemahaman pembelajaran materi fiqih thaharah dibandingkan dengan metode pembelajaran sebelumnya yakni ceramah. Hal ini terbukti dari hasil evaluasi belajar santri diakhir pelajaran tersebut baik berupa bacaan doa, hafalan maupun praktek.
\end{abstract}

Kata Kunci: Fiqh, Thaharah, Media, Audio, Visual

Manazhim : Jurnal Manajemen dan Ilmu Pendidikan

Volume 3, Nomor 1, Februari 2021; 127-135

https:// ejournal.stitpn.ac.id/index.php/manazhim 


\section{PENDAHULUAN}

Fiqih thaharah (bersesuci) menduduki masalah yang paling utama dalam islam, Para ahli fiqih bahkan mengutamakan pembahasan mengenai thaharah sebelum pembahasaan shalat, karena thaharah (bersesuci) merupakan dasar dari syarat sahnya shalat. Allah swt tidak menerima seorang hamba yang tidak bersesuci dalam melaksanakan ibadah, karena syarat dalam beribadah itu ialah bersesuci, baik dari najis maupun dari hadats. Pada dasarnya tujuan bersesuci merupakan cara umat muslim terhindar dari debu atau kotoran sehingga secara segaja atau tidak sengaja membatalkan ibadah kita kepada Allah SWT' ${ }^{1}$. Untuk itu penting bagi kita mempelajari thaharah, apalagi diusia dini, karna sejatinya thaharah wajib diajarkan kepada anak sebelum dia mencapai baligh, agar ketika mencapai baliqh mereka sudah memahami apa thaharah (bersesuci). Seorang muslim harus mengetahui hal tersebut, mulai dari hukum, syarat-syarat, serta tata cara pelaksanaannya ${ }^{2}$.

Pembahasan thaharah mencangkup dua pokok pembahasan dalam fiqih yaitu, bersesuci dari najis maupun hadast. Tanpa thaharah mustahil akan terwujud ibadah yang sah karena ibadah yang dilakukan seorang hamba harus dalam keadaan yang bersih dan suci (thaharah wa nadhafah) untuk meraih kesempurnaan ibadah ${ }^{3}$. Saat ini banyak kita jumpai anak-anak kurang memahami tentang thaharah (bersesuci) atau tata cara dalam bersesuci dengan benar menurut syariat islam, misalnya berwudhu' mereka cenderung melakukannya saja tanpa tau apakah whudu' yang mereka lakukan sudah benar atau tidak dengan syariát islam. Maka untuk memahami thaharah yang sebenarnya, umat islam diharuskan atau dianjurkan untuk mempelajari makna thaharah ${ }^{4}$. Dengan begitu santri bisa memahami thaharah serta dapat mengamalkannya dengan benar dalam kehidupannya sehari-hari.

Sebelumnya telah ada beberapa peneliti yang menuliskan tentang pembelajaran thaharah seperti Tri Rahayu dan M.Rosyid, hasil dari penelitiannya ialah

\footnotetext{
${ }^{1}$ Hikmatu Ruwaida, "Strategi Pembelajaran Fiqih Thaharah Di Sdn Mundar Kecamatan Lampihong Kabupaten Balangan," Al-Madrasah: Jurnal Pendidikan Madrasah Ibtidaiyah 3, no. 2 (2019): 167.

${ }^{2}$ Ahmad Hasyim Fauzan, "Abdi Kami”" 1, no. 2 (2019): 13-25.

3amaluddin Jamaluddin, "Fiqh Al-Bi'ah Ramah Lingkungan; Konsep Thaharah Dan Nadhafah Dalam Membangun Budaya Bersih," Jurnal Pemikiran Keislaman 29, no. 2 (2018): 324-346.

${ }^{4}$ Azimahrani Hasibuan and Ahmad Adib Nasution, "PENERAPAN METODE LEARNING TOGETHER PADA MATA” 10, no. 1 (2020).
} 
pendidik atau guru membut suasana pembelajaran lebih menarik dan beragam agar siswanya lebih tertarik mengikuti pelajaran. selanjutnya Imroatul Arifah, Ika Ratih Sulistiani dan Muhammad Afifulloh melakukan penelitian serupa. Disebutkan Dalam penelitian tersebut peneliti menjabarkan serta menganalisis keterampilan bersuci siswa, mengetahui sejauh mana wawasan siswa, serta kendala-kendala yang dijumpai dalam praktek thaharah. Keduanya sama-sama menjelaskan tentang thaharah, penelitian-penelitian tersebut belum mengaplikasikan media pembelajaran. Sedangkan penelitian ini dalam proses penyampaiannya memakai media audio visual. tujuannya agar memudahkan santri untukmemahami serta mempraktekkan materi thaharah. Media audio visual bisa memperlancar pemahaman, menguatkan ingatan, meningkatkanatensi siswa serta bisa memberikan hubungan antara materi pelajaran dengan dunia nyata ${ }^{5}$.

Pemanfaatan media pembelajaran dalam penyampaian materi terbilang penting, karena bisa memudahkan santri dalam memahami materi yang disalurkan oleh media tersebut. Santri dinilai lebih aktif menerima materi yang menarik dari pada materi yang penyampaiannya secara konvensional atau menggunakan metode ceramah. santri merasa bahwasanya hal tersebut cenderung membosankan, sehingga materi pembelajaran yang diterangkan oleh ustadnyasulit dipahami. Dengan menggunakan media pembelajaran selama proses belajar materi akan mudah tersampaikan dan dimengerti oleh santri. Penggunaan media pembelajaran dinilai bisa memotivasi santri untuk belajar lebih giat. Karena santri tidak mudah bosan saat pembelajaran berlangsung. Suasana belajar dikelas akan lebih efektif dan efisien karena pemanfaatan teknologi memberikan dampak positif terhadap minat dan kemampuan siswa. ${ }^{6}$.

Taman pendidikan Al-Qurán (TPQ) Al-Istiqomah adalah TPQ yang berada di desa Randujalak kecamatan Besuk kabupaten Probolinggo, dan satu-satunya TPQ yang mengajarkan santrinya Al-Qurán dan dilengkapi dengan ilmu lain atau pelajaran lain untuk melengkapi pengetahuan santri, seperti, Fiqih, Tauhid dan sebagainya.

5Zulkifli Rusby, Najmi Hayati, and Indra Cahyadi, "Upaya Guru Mengembangkan Media Visual Dalam Proses Pembelajaran Fiqih Di MAN Kuok Bangkinang Kabupaten Kampar” (2017): 18-37.

"Najmi Hayati and Febri Harianto, "Hubungan Penggunaan Media Pembelajaran Audio Visual Dengan Minat Peserta Didik Pada Pembelajaran Pendidikan Agama Islam Di SMAN 1 Bangkinang Kota," Al-Hikmah: Jurnal Agama dan Ilmu Pengetahuan 14, no. 2 (2017): 160-180. 
Selain itu TPQ ini mengajarkan praktek bagaimana cara berwudlu, shalat dan beberapa kegiatan lainnya.

Seperti yang telah disampaikan sebelumnya, fiqih merupakan salah satu pelajaran yang diajarkan dalam TPQ Al-Istiqomah. Thaharah salah satunya. Sulitnya materi tentang thaharah menyebabkan santri kurang memahami dan menguasainya. proses penyampaian pembelajaran disana menerapakan metode ceramah, metode ceramah kurang efektif jika diterapkan pada pembelajaran tersebut, karena santri bersikap pasif serta mudah bosan, mereka cenderung mendengarkan saja yang diterangkan, sehingga mereka tidak menangkap maksud yang disampaikan. Terkadang santri juga tidak fokus mendengarkan yang dijelaskan oleh guru. Salah satu faktor keberhasilan belajar ialah penerapan metode pembelajaran. guru wajib memanfaatkan bermacam-macam metode, sehingga kegiatan belajar menyenangkan. Serta santri termotivasi untuk belajar dengan begitu santri akan menangkap materi yang diajarkan dengan baik ${ }^{7}$.

Penggunaan metode ceramah, kurang efektif ketika disampaikan dalam bab thaharah ini, karena ada beberapa materi didalam thaharah yang diperlukan konsentrasi santri saat proses pemahamannya. Oleh sebab itu dibutuhkan metode atau media pembelajaran yang menarik perhatian santri serta sesuai dengan usia santri. media tersebuttentu membangkitkan alat indra santri selama pembelajaran berlangsung, semakin menarik media yang digunakan semakin meningkat pula kemauan santri untuk belajar. Metode ceramah dengan menggabungkan media merupakan suatu inovasi baru dalam penerapan media pembelajaran, dengan begitu akan lebih banyak alat indra santri yang terlibat ${ }^{8}$. Contohnya ialah dengan memvariasikan metode ceramah dengan media audio visual.

Media audio visual amat efektif diterapkan. Menariknya media ini menampilkan beragam audio dan visual menarik dan tentunya disukai oleh santri. Misalnya menampilkan vidio pembelajaran thaharah tahapan atau tata cara berwudlu.

${ }^{7} \mathrm{H}$ Hudatullah, "H. Hudatullah, Thaharah Dalam Metode.... Ta'dib : Volume 16, No 2 ( Juli- Des 2018 )" 16, no. 2 (2018): 1-10.

${ }^{8}$ Sari Kumala and Abdul Hafizh, "Penggunaan Media Audio Visual Dalam Kemampuan Mempraktikkan Bacaan Dan Gerakan Shalat Pada Pembelajaran Fiqih Pada Madrasah Ibtidaiyah Darul Ilmi Banjarbaru," Al-Madrasah: Jurnal Pendidikan Madrasah Ibtidaiyah 3, no. 2 (2019): 189. 
Adanya media audio visual sebagai sarana alteratif dalam proses pembelajaran. Apabila dibandingkan dengan hanya menggunakan metode ceramah serta media kovensional yang tentunyamembuat santri-santri bosan.

Berdasarkan penjabaran yang telah dijelaskan dapat dibuat rumusan masalah bagaimanakahpeningkatan pemahaman thaharah terhadap santri diterapkan di TPQ Al-Istiqomah melalui teknik yang diusulkan. Tujuan yang telah ditentukan sebelumnyayaitu pemahaman santri terhadap thaharah melalui teknik unik tersebut. Sehingga santri menerapkannya pada kehidupannya sendiri dan disekitarnya.

\section{METODE PENELITIAN}

Tempat pelaksanaan penelitian ini di TPQ Al-Istiqomah yang berada di desa Randujalak Besuk. Pendekatan yang digunakan ialah kualitatif. Pendekatan kualitatif ialah pendekatan penelitian yang berdasarkan pada proses untuk menjadikan sesuatu, bukan pada hasilnya'. Studi kasus merupakan jenis penelitian yang dipakai. Permasalahan yang perlu diperbaiki melaui penelitian ini ialah pemahaman santri terhadap thaharah yang harus lebih ditingkatkan.

Adapun teknik pengumpulan data pada penelitian ini menggunakan teknik dokumentasi, observasi dan wawancara. Data diperoleh melalui proses pengamatan langsung. Pengamatan diperoleh berupa data atau keterangan mengenai keterampilan santriterkait bersesuci dengan mengamati secara langsung. Sumber data diperoleh melalui wawancara secara langsungdengan melakukan tanya jawab kepada ustadz sebagai pengajar di TPQ Al-Istiqomah. Adapun data dalam penelitan ini ialah reduksi data, penyajian data serta penarikan kesimpulan.

${ }^{9}$ Tri Rahayu, "Upaya Guru Fikih Dalam Meningkatkan Pemahaman Siswa” 1, no. 2 (2019). 


\section{HASIL DAN PEMBAHASAN}

\section{Penggunaan Media Audio Visual Pada Pembelajaran Fiqih Thaharah di TPQ Al-Istiqomah}

\section{a. Perencanaan Guru dalam Pengguanaan Media Audio Visual di TPQ}

\section{Al-Istiqomah materi Fiqih Thaharah}

Tahap perencanaan dalam menerapkan media audio visual sangat diperlukan, karena harus memeperhatikan materi fiqih thaharah yang akandisampaikan sesuai tingkat atau kelas. Terkait pembagian materi ini dibagi menjadi 3 tingkat/kelas, kelas 1 sampai kelas 2 akan diberikan materi tentang hadas, sedangkan kelas 3 diajarkan tentang materi najis. Tujuan pembagian kelas ini menyesuaikan tingkat kemudahan dan kerumitan penguasaan materi berdasarkan usia santri. Sehingga penerapan media audio visual tidak keluar dari isi materi yang diajarkan, sehingga dengan begitu akan tepat sasaran serta sesuai target luaran yang diingankan.

Selain perencanaan materi pembejaran dalam penerapan media audio visual, guru wajib memperhatikan ketersediaan sarana prasarana guna menunjang proses pembelajaran dengan menggunakan media audio visual supaya berjalan secara efektif juga efisien. Sarana prasarana yang wajib tersedia di TPQ Al-Istiqomah diantaranya computer/laptop maupun LCD.

\section{b. Keterampilan Guru dalam Menggunakan Media Audio Visual pada} Materi Fiqih Thaharah

Guru professional akan mampu menyampaikan dan mendemonstrasikan beberapa keahlian mengajar sesuai dengan lingkungannya. Penguasaan terhadap berbagai keahlian dasar mengajar akan mampu mengatasi masalah pada saat proses belajar-mengajar, dengan begitu pembelajaran akan berjalan efektif dan efisien. Keterampilan guru ketika mengajar merupakan suatu komponen dalam pembentukan kemampuan profesional seorang guru.

Peningkatan keterampilan guru/ustadz dalam penggunaan media audio visual dalam materi fiqih thaharah di TPQ Al-Istiqomah, akan dilakukan pendampingan dalam proses penyampaian materi tersebut. pendampingan ini akan dilakukan oleh peneliti agar guru/ustadz dapat menggunakan dan mengembangkan penggunaan 
media audio visual dalam jangka panjang. Hal ini dilakukan supaya pembelajaran fiqih thaharah sepenuhnya tersampaikan secara efektif serta mudah dengan memanfaatkan media audio visual.

Pemanfaatan media audio visual saat proses pembelajaran di TPQ AIstiqomah, secara tidak langsung meningkatkan keterampilan mengajar dalam mengembangkan model penyampaian materi yang sebelumnya dilakukan dalam bentuk ceramah. Guru dirasa akan terampil dalam menyampaikan isi materi dengan menggunakan media audio visual. Penyampaan materi ditampilkan melalui LCD dan materi yang disampakan akan menarik perhatian siswa dengan menampakkan gambar, suara, gerakan-gerakan dan film pendek disediakan.

\section{c. Hambatan dalam Penggunaan Media Audio Visual pada Materi Fiqih Thaharah}

Pengimplemantasian media pembelajaran ketika proses belajar mengajar hanya untuk mempermudah guru dalam meningkatkan pengalaman belajar pada arah yang lebih konkrit. Peranan media pembelajaran sangat penting, ketika proses transfer ilmu pengetahuan, karena dengan media pembelajaran santri akan lebih termotivasi, serta memberikan pengalaman belajar yang berbeda dan mempermudah santri dalam memahami materi yang telah disampaikan.

Audio visual di TPQ A-Istiqomah memiliki kendala dalam pelaksanaannya. Kendala tersebut berkaitan dengan kesalahan teknis, misalnya, jek kabel penghubung antara LCD ke laptop terkadang tidak konek, masalah daya listrik yang kurang, sehingga listrik sering padam jika menggunakan perangkat-perangkat yang terhubung dengan aliran listrik melibihi kapasitas daya listrik yang dimiliki. Selain itu ketika jam pelajaran sedang berlangsung ternyata ada pemadaman listrik, maka pembelajaran audio visual otomatis terhenti dan beralih pada pembelajaran sebelumnya, yakni pembelajaran ceramah.

Selain kendala kesalahan teknis, terdapat masalah dalam pembelajaran media audio visual yakni keterbatasan alokasi dana. Masalah tersebut adalah hal yang klasik dalam penggunaan media audio visual. Dana tersebut akan digunakan untuk perawatan dan pembaharuan sarana prasarana yang berkaitan dengan penggunaan 
media pembelajaran audio visual. Masalah terakhir dalam penerapannya juga terletak pada pencahayaan, cahaya yang terlalu terang akan mempengaruhi penyajian materi yang disampaikan melalui media audio visual.

\section{d. Hasil belajar Santri Setelah Guru Menggunakan Media Audio Visual pada Materi Fiqih Thaharah di TPQ Al-Istiqomah}

Hasil belajar merupaan tolak ukur sukses tidaknya pembelajaran di suatu lembaga pendidikan. Hasil belajar juga merupakan hasil dari teknik pembelajaran yang diperoleh oleh peserta didik yang berupa keterampilan motorik, kognitif dan spontan yang bisa dilihat setelah proses pembelajaran selesai, karena keberhasilan pendidikan salah satunya ditunjukan dengan semakin meningkatnya hasil belajar santri. Faktor penentu tinggi redahnya hasil belajar santri salah satunya adalah pemakaian media pembelajaran dalam proses penyampaian materi.

Hasil santri TPQ Al-Istiqomah di buktikan dengan nilai evaluasi belajar santri setiap akhir semester. Peningkatan hasil belajar santri juga dirasakan saat guru menggunakan media audio visual, ketika proses penyaampaian materi santri menyimak dengan baik, aktif bertanya dan termotivasi serta cepat memahami, menghafal dan mempraktekkan materi yang disampaikan tersebut. sehingga memberikan peningkatan pada hasil belajar santri.Selain memaksimalkan hasil belajar, pemanfaatan media audio visual juga untuk melatih santri dalam mempraktekkan materi thaharah khususnya langkah-langkah bersuci dalam kehidupan sehari-hari.

\section{KESIMPULAN}

Berdasarkan pembahasan pada bagian sebelumnya, pemanfaatan media pembelajaran audio visual sangat perlu diterapkan ketika proses belajar mengajar khususnya pembelajaran fiqih thaharah di TPQ Al-Istiqomah. Sejalan degan tujuannya, yakni agarpeningkatan pemahaman santri terhadap pembelajaran thaharah serta mampu mengamalkannya pada kehidupannya sendiri dan sekitarnya melalui media audio visual. Peningkatan pemahaman santri dapat diketahui melalui hasil evaluasi belajar santri. 
Penggunaan media pembelajaran audio visual juga bertujuan untuk meningkatkan keterampilan guru ketika penyampaian materi fiqih thaharah yang sebelumnya hanya melalui metode ceramah. Metode ceramah terbukti kurang efisien untuk diterapkan, karena santri akan mudah bosan dan tidak fokus dalam memahmi pelajaran yang disampaikan. Dengan begitu media audio visual yang menyajikan materi secara menarik melalui gambar, suara, gerakan dan video tatacara bersuci akan lebih disukai santri sehingga peningkatan pemahaman santri terhadap materi tersebut jauh lebih efisien dan lebih mudah diterapkan dalam kehidupan sehari-hari.

\section{DAFTAR PUSAKA}

Fauzan, Ahmad Hasyim. "Abdi Kami” 1, no. 2 (2019): 13-25.

Hasibuan, Azimahrani, and Ahmad Adib Nasution. "PENERAPAN METODE LEARNING TOGETHER PADA MATA” 10, no. 1 (2020).

Hayati, Najmi, and Febri Harianto. "Hubungan Penggunaan Media Pembelajaran Audio Visual Dengan Minat Peserta Didik Pada Pembelajaran Pendidikan Agama Islam Di SMAN 1 Bangkinang Kota." Al-Hikmah: Jurnal Agama dan Ilmu Pengetabuan 14, no. 2 (2017): 160-180.

Hudatullah, H. "H. Hudatullah, Thaharah Dalam Metode.... Ta'dib : Volume 16, No 2 (Juli- Des 2018 )" 16, no. 2 (2018): 1-10.

Jamaluddin, Jamaluddin. "Fiqh Al-Bi'ah Ramah Lingkungan; Konsep Thaharah Dan Nadhafah Dalam Membangun Budaya Bersih." Jurnal Pemikiran Keislaman 29, no. 2 (2018): 324-346.

Kumala, Sari, and Abdul Hafizh. "Penggunaan Media Audio Visual Dalam Kemampuan Mempraktikkan Bacaan Dan Gerakan Shalat Pada Pembelajaran Fiqih Pada Madrasah Ibtidaiyah Darul Ilmi Banjarbaru." Al-Madrasab: Jurnal Pendidikan Madrasah Ibtidaiyah 3, no. 2 (2019): 189.

Rahayu, Tri. "Upaya Guru Fikih Dalam Meningkatkan Pemahaman Siswa" 1, no. 2 (2019).

Rusby, Zulkifli, Najmi Hayati, and Indra Cahyadi. "Upaya Guru Mengembangkan Media Visual Dalam Proses Pembelajaran Fiqih Di MAN Kuok Bangkinang Kabupaten Kampar” (2017): 18-37.

Ruwaida, Hikmatu. "Strategi Pembelajaran Fiqih Thaharah Di Sdn Mundar Kecamatan Lampihong Kabupaten Balangan." Al-Madrasab: Jurnal Pendidikan Madrasah Ibtidaiyah 3, no. 2 (2019): 167. 